\title{
Design, construction and testing of a floating hood biodigester prototype for municipal waste organic waste
}

\section{Diseño, construcción y prueba de prototipo biodigestor de campana flotante para residuos orgánicos de rastro municipal}

ACOSTA-PINTOR, Dulce Carolina†**, MOJICA-MESINAS, Cuitláhuac, VIDAL-BECERRA, Eleazar and GONZÁLEZ-ZARAZÚA, Jonathan de Jesús Constantino

Tecnológico Nacional de México - Campus Ciudad Valles, Carretera al Ingenio Plan de Ayala Km. 2, Colonia Vista Hermosa, C.P. 79010, Ciudad Valles, S.L.P.

ID $1^{\text {st }}$ Author: Dulce Carolina, Acosta-Pintor / ORC ID: 0000-0003-0784-7039, Researcher ID Thomson: T-3349-2018, arXiv Author ID: DulceAcosta, CVU CONACYT ID: 626925

ID $1^{\text {st }}$ Co-author: Cuitláhuac, Mojica-Mesinas / ORC ID: 0000-0001-8585-8249, Researcher ID Thomson: T-3267-2018, arXiv Author ID: MOMC640319JF8, CVU CONACYT ID: 744041

ID $2^{\text {nd }}$ Co-author: Eleazar, Vidal-Becerra / ORC ID: 0000-0003-3857-2103, Researcher ID Thomson: T-1547-2018, arXiv Author ID: elia.vidal, CVU CONACYT ID: 623037

ID $3^{\text {rd }}$ Co-author: Jonathan de Jesús Constantino, González-Zarazúa / ORC ID: 0000-0002-8386-225X, arXiv Author ID: Jonathan19, CVU CONACYT ID: 1167523

DOI: $10.35429 / J O E S .2021 .25 .8 .22 .29$

Received 09 July, 2021; Accepted 28 November, 2021

\section{Abstract}

This paper documented the design, construction and operation test of a floating hood biodigester prototype, using organic residues (ruminal content, blood, bovine excreta and viscera) from the municipal trail of Ciudad Valles, S.L.P., with the purpose of generating biogas. The components of the biodigester system considered were: loading duct, concrete biodigester tank, biogas pipeline, floating hood, gas reservoir, discharge duct and discharge tank. A biodigester with storage capacity in the $0.178 \mathrm{~m}^{3}$ floating hood was designed for a 30-day trial operation and storage of $0.120 \mathrm{~m}^{3}$ of organic waste mixture in the biodigester tank. As of day 17 of operation the daily average of biogas generated was $0.1801 \mathrm{~m}^{3}$. The composition of the biogas at day 30 of operation, showed a content of $59.4 \%$ of $\mathrm{CH}_{4}$. When performing the flame test, an intense blue coloration was obtained, which indicates that the biogas produced has a high calorific value that will allow heating and flammability.

Biodigester, Floating hood, Organic waste, Municipal trail

\section{Resumen}

En este trabajo se documentó el diseño, construcción y prueba de funcionamiento de prototipo biodigestor de campana flotante, utilizando residuos orgánicos (contenido ruminal, sangre, excretas de ganado bovino y trozos de vísceras) del rastro municipal de Ciudad Valles, S.L.P., con la finalidad de generar biogás. Los componentes del sistema biodigestor considerados fueron: conducto de carga, tanque biodigestor de concreto, tubería de conducción de biogás, campana flotante, reservorio para gas, conducto de descarga y tanque de descarga. Se diseñó un biodigestor con capacidad de almacenamiento en la campana flotante de $0.178 \mathrm{~m}^{3}$ para una operación de 30 días de prueba y almacenamiento de $0.120 \mathrm{~m}^{3}$ de mezcla de residuos orgánicos en tanque biodigestor. A partir del día 17 de operación el promedio diario de biogás generado fue de $0.1801 \mathrm{~m}^{3}$. La composición del biogás al día 30 de operación, mostró un contenido de $59.4 \%$ de $\mathrm{CH}_{4}$. Al realizar la prueba de llama, se obtuvo una coloración azul intensa, lo que indica que el biogás producido posee un alto poder calorífico que permitirá el calentamiento e inflamabilidad.

Biodigestor, Campana flotante, Residuos orgánicos

Citation: ACOSTA-PINTOR, Dulce Carolina, MOJICA-MESINAS, Cuitláhuac, VIDAL-BECERRA, Eleazar and GONZÁLEZ-ZARAZÚA, Jonathan de Jesús Constantino. Design, construction and testing of a floating hood biodigester prototype for municipal waste organic waste. Journal of Experimental Systems. 2021. 8-25: 22-29

\footnotetext{
* Correspondence to Author (email: dulce.acosta@tecvalles.mx)

$\dagger$ Researcher contributing as first Author.
} 


\section{Introduction}

In meat production, slaughterhouses are an important link in the production chain. In Mexico, there are 864 slaughterhouses and/or slaughter centers and 464 TIF slaughterhouses. Of these, in the State of San Luis Potosí there are 23 municipal slaughterhouses, two private slaughterhouses and eight TIF slaughterhouses (SENASICA, 2020).

The municipal slaughterhouse in Ciudad Valles, S.L.P. currently provides public slaughter services for cattle and swine. During slaughter, significant amounts of liquid and solid waste are generated, such as blood, urine, milk, gastrointestinal contents, bile, pieces of tissue, fat, hair, hooves, horns, etc., which are dragged with the water used for washing during and after slaughter to the collection and separation systems for solids, resulting in the presence of a variety of contaminants: physical, chemical, biological and microbiological.

According to a waste quantification study previously conducted at the municipal slaughterhouse, it was estimated that $21,388 \mathrm{~kg}$ of organic waste were generated per month, which represents $1,336.7 \mathrm{~kg}$ per day (16 days of waste generation), mainly a mixture of manure, bovine and pig blood, and bovine rumen content, so it is feasible to produce up to $1,625.95 \mathrm{~m} 3$ of biogas per month (Vidal, 2021).

It was identified that liquid waste (water and blood) is sent to the municipal wastewater treatment plant and solid waste from rumen, manure, hoof, tail and horns are taken to the sanitary landfill; this situation represents, in addition to the obvious environmental damage, a great waste of resources that can be valorized for biogas generation or can be considered a byproduct of slaughter. Due to the physical and chemical characteristics of the organic wastes derived from the slaughterhouse, they can be used and exploited for the generation of biogas.

The purpose of this work was to design and build a prototype floating hood biodigester to test the operation of organic waste digestion and evaluate its performance.
The reason why the study of the operation of this type of biodigester is required is because of the advantages it represents for the specific case of the municipal slaughterhouse of Ciudad Valles, considering that it has a limited space in the extension of land for the implementation of a taiwan or lagoon type biodigester. The floating bell biodigester has several advantages such as: years of useful life, smaller space requirement, vertical location, ease of maintenance and more durable construction materials (Hernández, A. 2013), which could be considered when implementing a project of this type in the field.

\section{Methodology to be developed}

For the design, construction and testing of the floating bell biodigester prototype, it was necessary to carry out four methodological stages:

\section{Stage 1. Design of the prototype floating hood biodigester}

For the realization of the prototype design, the ideation of the system was considered, and the following components were determined to degrade the biomass in single phase:

1. Loading duct: allows the biomass to enter from the load to the digester.

2. Concrete biodigester tank: where the decomposition of the biomass will be carried out according to the established retention time in the total absence of oxygen.

3. Biogas conduction piping: to transport the biogas from the digester to the floating bell.

4. Floating hood: made of galvanized sheet to allow the handling of biogas recovery.

5. Gas reservoir: bag for storage of the biogas generated.

6. Discharge duct: allows the exit of the stabilized material (sludge) after having completed the retention time inside the digester.

7. Discharge tank: this tank allows the accumulation of effluent and sludge as by-products of biomass biodegradation for later use. 
Once the system components were identified, the dimensions of the prototype were determined based on the mixing ratio to be used in the biodigester for a 30-day test operation. For this purpose, the calculations suggested by García, J. and León E. 2015 were used.

The design of the floating bell biodigester prototype considered its operation with a daily load in a $1: 3$ ratio of $1 \mathrm{~kg}$ of organic waste obtained from the municipal slaughterhouse of Ciudad Valles and 31 of water. The volume of the biodigester tank was sized to allow the digestion of $4 \mathrm{~kg}$ of mixture per day in 30 days of operation according to the following equation:

$V t b=C D * T R$

\section{Where:}

$V t b=$ Volume of the biodigester tank $\left(\mathrm{m}^{3}\right)$.

$C D=$ Daily load $(\mathrm{kg})$

$T R=$ Time in which the mixture remains inside the biodigester (days)

$V t b=\left(\frac{4 k g}{d a y} * \frac{1 m^{3} \text { mix }}{1000 \text { lmix }}\right) 30$ days $=0.12 m^{3}$

The mixture to be deposited in the loading tank will have a volume of $0.120 \mathrm{~m} 3$ in 30 days of operation. But it must be considered that this mixture will occupy $75 \%$ and the remaining $25 \%$ will be occupied by the biogas generated. Therefore, a calculation was made to determine the total volume required with equation 2 :

$V n b=V t b+V t b *\left(\frac{25}{100}\right)$

Where:

$V n b=$ net volume of the biodigester tank $\left(\mathrm{m}^{3}\right)$.

$V t b=$ biodigester tank volume $\left(\mathrm{m}^{3}\right)$

$25 \%=$ remaining percentage to be taken up by the biogas generated

$V n b=0.120 m^{3}+0.120 m^{3} *\left(\frac{25}{100}\right)=0.150 \mathrm{~m}^{3}$

The net volume of the biodigester tank necessary to deposit the raw material for 30 days was calculated at $0.150 \mathrm{~m}^{3}$. In the case of this prototype, a concrete pipe was used as a biodigester tank. The calculated volume of the concrete pipe purchased and used for the biodigester meets the volume required to conserve the organic mixture.
For the sizing of the floating hood, the measurements of the biodigester tank were considered, calculating the diameter of the hood with the following equation:

$\emptyset$ hood $=\varnothing$ biodigester tan $-0.02 m$

Where:

$\emptyset$ hood $=$ hood diameter $(m)$

$\emptyset$ biodigester tank $=\quad$ biodigester tank diameter $(m)$

$0.02=$ decrease to biodigester tank diameter $(\mathrm{m})$

$\emptyset$ hood $=0.44 m-0.02 m=0.42 \mathrm{~m}$

The diameter of the bell was calculated to be $0.42 \mathrm{~m}$. In addition, the height of the floating hood was determined to be $0.30 \mathrm{~m}$, less than the total height of the biodigester tank, that is, $1.15 \mathrm{~m}$ in height from its base to the beginning of the dome and $0.21 \mathrm{~m}$ the height of the floating hood dome, to obtain by equation 4 , the total height of the floating hood from the following equation:

$H T_{\text {hood }}=H_{\text {hood }}+H_{\text {dome }}$

Where:

$H T_{\text {hood }}=$ floating hood height $(\mathrm{m})$

$H_{\text {dome }}=$ floating hood dome height $(\mathrm{m})$

$H T_{\text {hood }}=1.15+0.21=1.36 \mathrm{~m}$

With these data, the radius of curvature of the dome was obtained by the following equation:

$R_{\text {curv }}=\frac{\left(r_{\text {hood }}\right)^{2}+\left(h_{\text {dome }}\right)^{2}}{2\left(h_{\text {dome }}\right)}$

Where:

$r_{\text {hood }}=$ hood radius $(m)$

$h_{\text {dome }}=$ dome height $(\mathrm{m})$

$R_{\text {curv }}=\frac{(0.21)^{2}+(0.21)^{2}}{2(0.21)}=0.21 \mathrm{~m}$

The radius of curvature of the dome was calculated to be $0.21 \mathrm{~m}$. To obtain the volume of the bell and the volume of the bell dome, equations 6 and 7 were applied:

$V_{\text {hood }}=\pi h r^{2}$

Where:

$h=$ height of the hood $(m)$

$r=$ hood radius $a(m)$

ACOSTA-PINTOR, Dulce Carolina, MOJICA-MESINAS, Cuitláhuac, VIDAL-BECERRA, Eleazar and GONZÁLEZ-ZARAZÚA, Jonathan de Jesús Constantino. Design, construction and testing of a floating hood biodigester prototype for municipal waste organic waste. Journal of Experimental Systems. 2021 
$V_{\text {hood }}=\pi(1.15)(0.21)^{2}=0.159 \mathrm{~m}^{3}$

$V_{\text {dome }}=\pi\left(h_{\text {cup }}\right)^{2}\left(R_{\text {curv }}-\frac{h_{\text {cup }}}{a}\right)$

Where:

$h_{\text {dome }}=$ height of the dome $(m)$.

$R_{\text {curv }}=$ radius of curvature $(\mathrm{m})$

$a=3$ constant value

$V_{\text {dome }}=\pi(0.21)^{2}\left(0.21-\frac{0.21}{3}\right)=$ $0.0193 \mathrm{~m}^{3}$

The volume of the bell and the dome were calculated as $0.159 \mathrm{~m}^{3}$ and $0.0193 \mathrm{~m}^{3}$ respectively. With these data obtained, the total volume of the floating bell according to the following equation was considered to be:

$V t_{\text {hood }}=V_{\text {hood }}+V_{\text {dome }}$

$V t_{\text {hood }}=0.159+0.0193=0.178 \mathrm{~m}^{3}$

The design of the hood considers a total storage volume of $0.178 \mathrm{~m}^{3}$, which will be sufficient to cover the calculated theoretical daily capacity of $0.0760 \mathrm{~m}^{3}$ of biogas generated from municipal slaughterhouse waste. With this data, the design and dimensions of the biodigester prototype were elaborated in AutoCAD.

\section{Stage 2 Construction of the floating bell biodigester prototype}

The construction of this biodigester prototype was carried out within the Ciudad Valles Campus, where space, water and security were provided for access to it. The nursery area of the Campus was chosen with an extension of 330 $\mathrm{m}^{2}$, the site was cleaned by removing the weeds, the area of approximately $58.9 \mathrm{~m}^{2}$ was delimited for the construction of the prototype and the land was excavated with the support of hand tools, considering a vertical area of $1 \mathrm{~m}$ for the subsequent placement of the biodigester.

For the construction of the biodigester tank, a $1.45 \mathrm{~m}$ long concrete pipe with a diameter of $0.44 \mathrm{~m}$ and a thickness of 3 inches was prepared; two $0.08 \mathrm{~m}$ diameter holes were drilled to allow the biomass to enter the biodigester and the effluents to exit.
Subsequently, the bottom of the excavation was tiled using wire mesh, cement, gravel and sand to lay the base of the concrete pipe, waiting for it to set for 24 hours, after which the sealing was verified. The concrete structure was waterproofed internally and externally to prevent future leaks during the operation (see Figure 1).

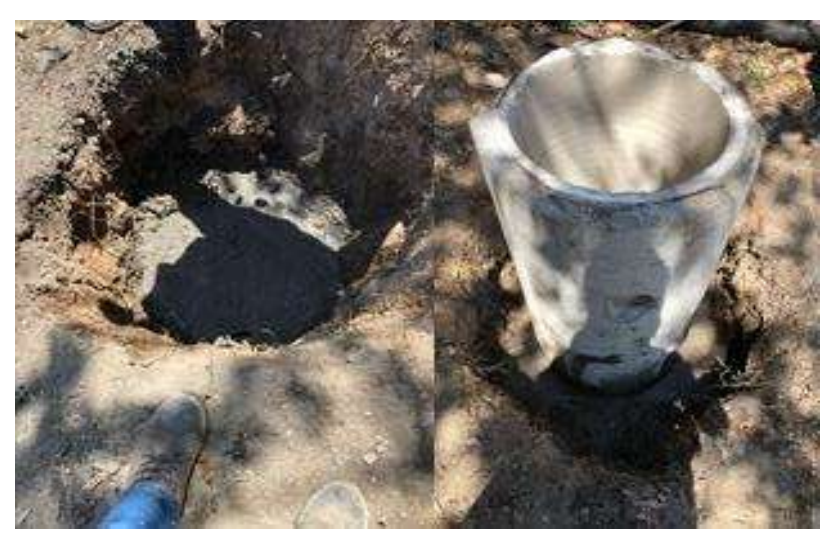

Figure 1 Tiling and placement of the concrete pipe Own Source

The biodigester tank was also fitted with 3-inch PVC pipes sealed with silicone and white cement to supply and discharge the effluents. A straight slope was considered in the ducts to prevent the materials from clogging and thus facilitate maintenance during operation (see Figure 2). A 20-liter container connected to the duct was used as a discharge tank.

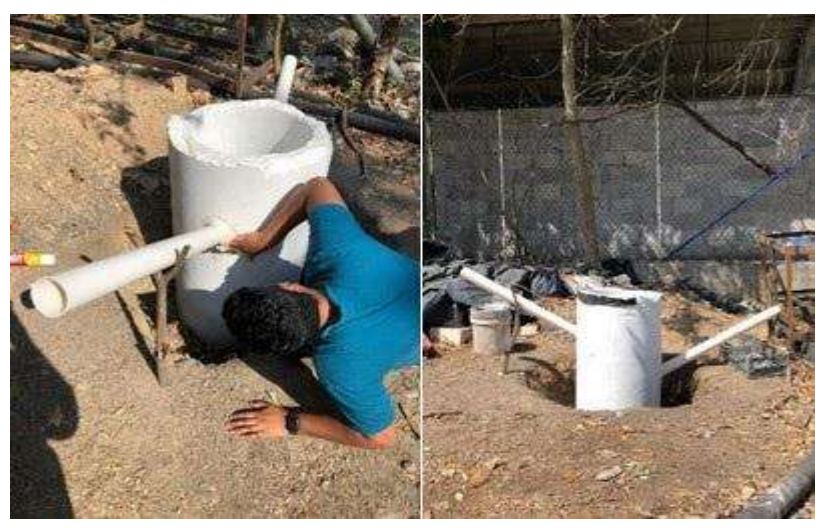

Figure 2 Placement of loading and unloading ducts Own Source

For the construction of the biodigester's floating hood, 28-gauge galvanized steel sheet with a conical finish was used, with a total height of the hood of $1.36 \mathrm{~m}$ (1.15 m hood height and $0.21 \mathrm{~m}$ dome height), and a diameter of $0.42 \mathrm{~m}$. The separation between the walls of the biodigester and the dome was $0.42 \mathrm{~m}$. 
The separation between the walls of the biodigester and the body of the floating hood was aligned at $0.02 \mathrm{~m}$, in order to allow it to rise and fall normally once the biodigestion process generates biogas. The floating hood was also waterproofed internally and externally to avoid possible leaks. Once finished, it was inserted into the biodigester (see Figure 3).

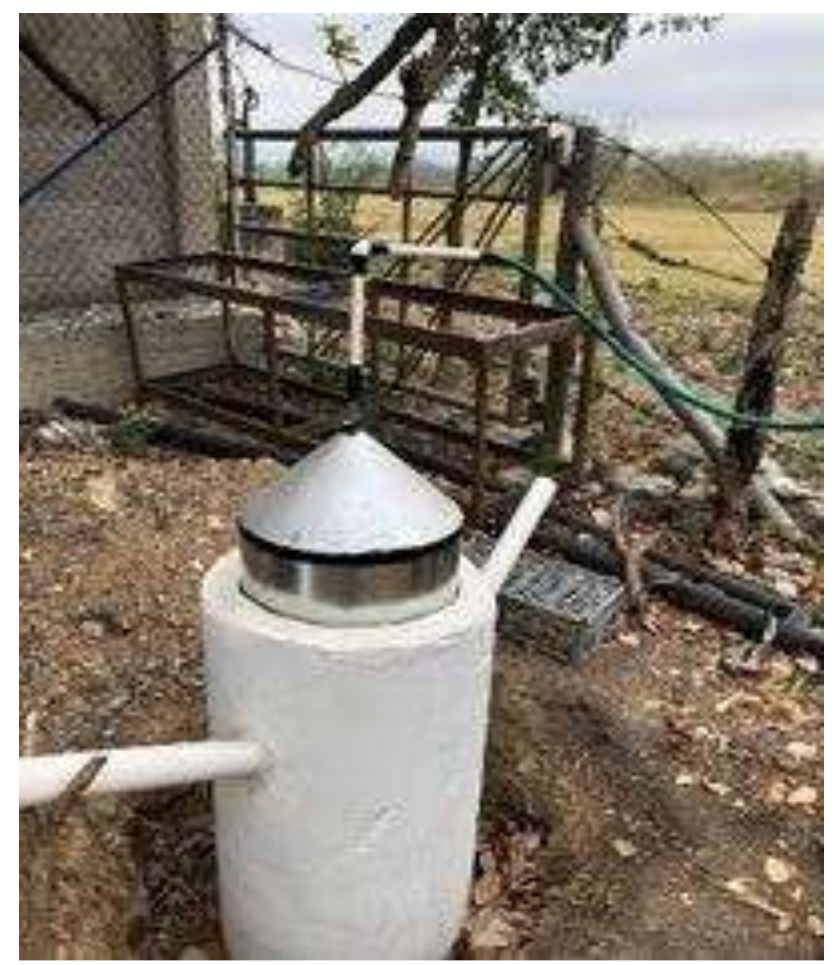

Figure 3 Placement of the floating hood Own Source

The biogas conduction pipe was installed from the floating hood, using a $1 / 2$ " PVC pipe, $0.40 \mathrm{~m}$ long, which was connected to a $1 / 2$ " valve to control the gas outlet directly from the hood. The connection to the reservoir was made with a $1 / 2$ " by $0.40 \mathrm{~m}$ long hose for the conduction of biogas from the floating bell to the reservoir. A geomembrane was considered for the reservoir with a storage capacity of $0.178 \mathrm{~m} 3$. For the water column meter, a $1 / 2$ " by $0.10 \mathrm{~m}$ long PVC pipe, a $1 / 2$ " coupling and a $1 / 2$ " by $0.02 \mathrm{~m}$ long PVC pipe were connected to measure the pressure of the biodigester system.

Finally, a hydrostatic test was performed to verify possible leaks in the biodigester, where the biodigester was filled with water and all of its elements were checked. Each connection was reinforced with insulating tape to avoid possible leaks that could alter the gas transport. (See figure 4).

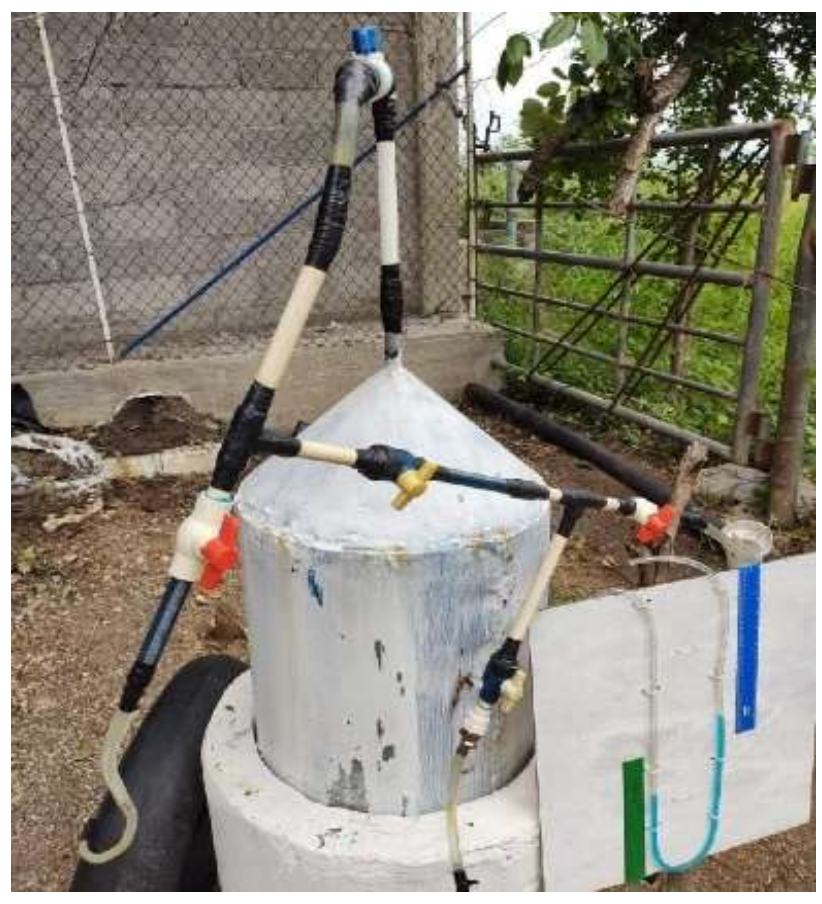

Figure 4 Floating hood biodigester prototype Own Source

\section{Stage 3 Monitoring of operating conditions during waste degradation}

Organic waste from the municipal slaughterhouse was fed for 30 consecutive days starting on June 8, 2021. To feed the biodigester, a 1:3 mixture was made, $1 \mathrm{~kg}$ of organic waste obtained from the municipal slaughterhouse (rumen content, blood, cattle excrement and pieces of viscera), and 31 of water, which was homogenized to enter through the biodigester loading duct (see Figure 5). A daily record was made of the amount of mixture loaded into the biodigester, $\mathrm{pH}$ and daily temperature to monitor the conditions of biogas production, the measurements were made with OAKTON PCD650 multiparametric equipment.

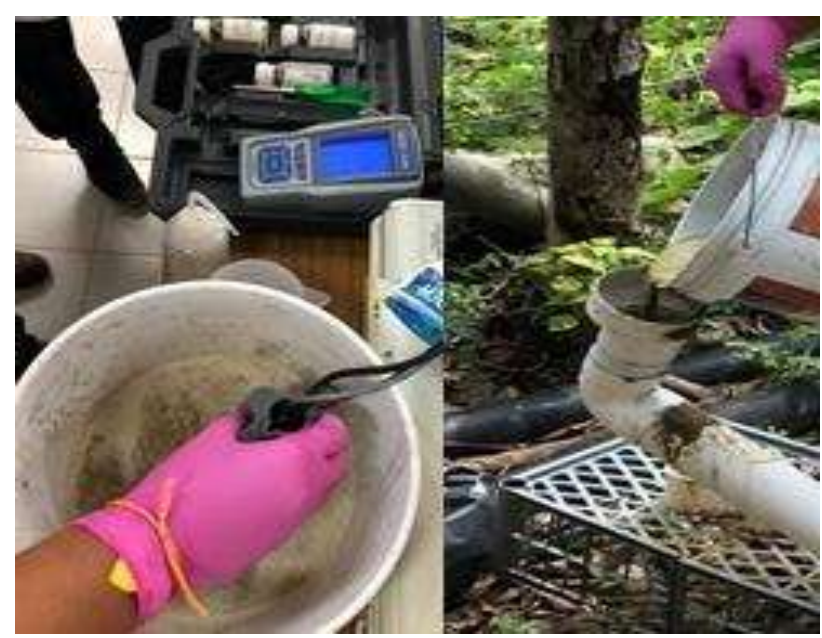

Figure 5 Preparation of organic waste and loading to biodigester Own Source

ACOSTA-PINTOR, Dulce Carolina, MOJICA-MESINAS, Cuitláhuac, VIDAL-BECERRA, Eleazar and GONZÁLEZ-ZARAZÚA, Jonathan de Jesús Constantino. Design, construction and testing of a floating hood Jesús Constantino. Design, construction and testing of a floating hood
biodigester prototype for municipal waste organic waste. Journal of biodigester prototype for municipal waste organic waste. Journal of
Experimental Systems. 2021 
The water column (mmWC) was also measured to calculate the biogas production generated from day 14 of operation. A Multitec model 540 device was used to measure biogas quality on day 30 of biodigester operation (see Figure 6).

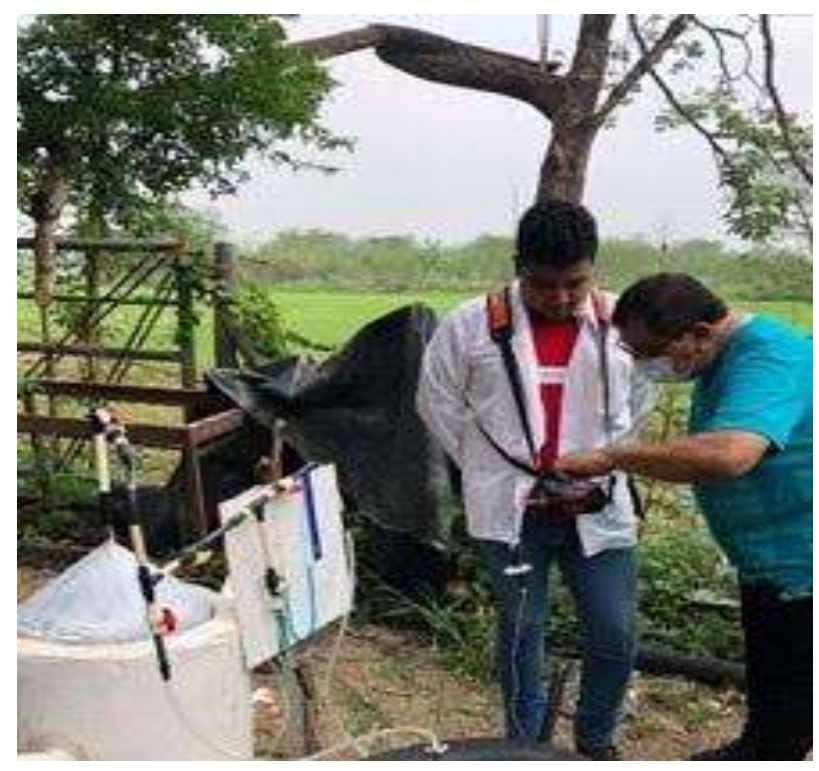

Figure 6 Biogas quality monitoring Own Source

The following physical-chemical parameters of the rumen content mixture to be used in biodigestion were also analyzed: $\mathrm{pH}, \%$ moisture, $\%$ total solids, $\%$ ash, $\%$ volatile solids, $\%$ lipids, $\%$ carbon, $\%$ nitrogen, carbon/nitrogen ratio.

\section{Stage 4. Flame test}

After 15 days of the initial load, it is recommended to start verifying the beginning of biogas production ( $\mathrm{CO} 2$ and $\mathrm{CH} 4$ in similar proportion), by means of the "biogas burning" verification. (FAO, 2011), so a flame test was performed.

\section{Results}

The results of each of the stages of the research were as follows:

\section{Stage 1 and 2. Design and construction of prototype floating bell biodigester}

A biodigester was designed with a storage capacity in the floating hood of $0.178 \mathrm{~m} 3$ for a 30-day test operation and storage of $0.120 \mathrm{~m} 3$ of organic waste mixture in the biodigester tank; considering that $1.0 \mathrm{~kg}$ of waste theoretically generates $0.0760 \mathrm{~m} 3$ of biogas per day.

\section{Stage 3 Monitoring of operating conditions during waste degradation}

A record of the amount of mixture poured into the biodigester, $\mathrm{pH}$ and daily temperature was made to monitor the biogas production conditions. Table 1 shows the results of the records observed. It should be noted that in this prototype biogas production began on day 14 of feeding, during which time the pressure was measured in mmCA and the volume of biogas generated in liters for 17 days, exceeding expectations of biogas production with an average of $0.1801 \mathrm{~m} 3$, so that the biodigester was depressurized on a daily basis. The results are shown in Table 2.

\begin{tabular}{|c|c|c|c|}
\hline Day & $\begin{array}{l}\mathrm{kg} \text { feed: } 1 \mathrm{~kg} \\
\text { beef } / 31 \text { water }\end{array}$ & $\mathrm{pH}$ & $\begin{array}{c}\text { Temperature } \\
{ }^{\circ} \mathrm{C}\end{array}$ \\
\hline 08/06/2021 & 4 & 7.11 & 24.6 \\
\hline $09 / 06 / 2021$ & 4 & 7.08 & 27.7 \\
\hline $10 / 06 / 2021$ & 4 & 7.09 & 25.7 \\
\hline $11 / 06 / 2021$ & 4 & 7.08 & 25.6 \\
\hline $12 / 06 / 2021$ & 4 & 7.09 & 24.8 \\
\hline $13 / 06 / 2021$ & 4 & 7.1 & 29.4 \\
\hline $14 / 06 / 2021$ & 4 & 7.1 & 26.2 \\
\hline $15 / 06 / 2021$ & 4 & 7.11 & 24.7 \\
\hline $16 / 06 / 2021$ & 4 & 7.1 & 27.3 \\
\hline $17 / 06 / 2021$ & 4 & 7.08 & 26.6 \\
\hline $18 / 06 / 2021$ & 4 & 7.12 & 27.2 \\
\hline $19 / 06 / 2021$ & 4 & 7.13 & 28 \\
\hline $20 / 06 / 2021$ & 4 & 7.14 & 25.8 \\
\hline $21 / 06 / 2021$ & 4 & 7.15 & 31.6 \\
\hline $22 / 06 / 2021$ & 4 & 7.15 & 25.5 \\
\hline $23 / 06 / 2021$ & 4 & 7.14 & 23.6 \\
\hline $24 / 06 / 2021$ & 4 & 7.14 & 23.4 \\
\hline $25 / 06 / 2021$ & 4 & 7.12 & 25.1 \\
\hline $26 / 06 / 2021$ & 4 & 7.04 & 24.5 \\
\hline $27 / 06 / 2021$ & 4 & 7.08 & 24.6 \\
\hline $28 / 06 / 2021$ & 4 & 7.13 & 21.1 \\
\hline $29 / 06 / 2021$ & 4 & 7.13 & 27.5 \\
\hline $30 / 06 / 2021$ & 4 & 7.15 & 24.6 \\
\hline $01 / 07 / 2021$ & 4 & 7.13 & 24.5 \\
\hline $02 / 07 / 2021$ & 4 & 7.13 & 25.2 \\
\hline $03 / 07 / 2021$ & 4 & 7.12 & 26.2 \\
\hline $04 / 07 / 2021$ & 4 & 7.13 & 23.8 \\
\hline $05 / 07 / 2021$ & 4 & 7.12 & 23.2 \\
\hline $06 / 07 / 2021$ & 4 & 7.12 & 22.4 \\
\hline $07 / 07 / 2021$ & 4 & 7.11 & 24.8 \\
\hline Average & 4 & 7.114 & 25.50 \\
\hline
\end{tabular}

Table 1 Quantities of organic matter introduced into the biodigester Own Source 


\begin{tabular}{|c|r|r|}
\hline Day & mmCA & $\mathrm{m}^{3}$ biogas produced \\
\hline $21 / 06 / 2021$ & 52 & 0.1794 \\
\hline $22 / 06 / 2021$ & 34 & 0.1790 \\
\hline $23 / 06 / 2021$ & 138 & 0.1810 \\
\hline $24 / 06 / 2021$ & 66 & 0.1796 \\
\hline $25 / 06 / 2021$ & 150 & 0.1812 \\
\hline $26 / 06 / 2021$ & 126 & 0.1807 \\
\hline $27 / 06 / 2021$ & 136 & 0.1809 \\
\hline $28 / 06 / 2021$ & 140 & 0.1810 \\
\hline $29 / 06 / 2021$ & 128 & 0.1808 \\
\hline $30 / 06 / 2021$ & 116 & 0.1805 \\
\hline $01 / 07 / 2021$ & 108 & 0.1804 \\
\hline $02 / 07 / 2021$ & 98 & 0.1802 \\
\hline $03 / 07 / 2021$ & 86 & 0.1800 \\
\hline $04 / 07 / 2021$ & 72 & 0.1797 \\
\hline $05 / 07 / 2021$ & 60 & 0.1795 \\
\hline $06 / 07 / 2021$ & 44 & 0.1792 \\
\hline $07 / 07 / 2021$ & 20 & 0.1787 \\
\hline Average & 92.5883 & 0.1801 \\
\hline
\end{tabular}

Table 2 Monitoring of $\mathrm{mmCA}$ and calculation of $\mathrm{m}^{3}$ biogas produced

Own source

On the 30th day of operation, a biogas quality measurement was carried out with a Multitec model 540 meter, where the biogas composition was identified. The results are shown in Table 3.

\begin{tabular}{|l|l|l|l|}
\hline \multicolumn{1}{|c|}{$\begin{array}{c}\text { Biogas } \\
\text { composition }\end{array}$} & Results & \multicolumn{1}{c|}{$\begin{array}{c}\text { Biogas } \\
\text { composition }\end{array}$} & Results \\
\hline $\begin{array}{l}\text { Methane } \\
\left(\mathrm{CH}_{4}\right)\end{array}$ & $59.4 \%$ & $\begin{array}{l}\text { Methane } \\
\left(\mathrm{CH}_{4}\right)\end{array}$ & $59.4 \%$ \\
\hline $\begin{array}{l}\text { Carbon } \\
\text { dioxide }\left(\mathrm{CO}_{2}\right)\end{array}$ & $37 \%$ & $\begin{array}{l}\text { Carbon } \\
\text { dioxide }\left(\mathrm{CO}_{2}\right)\end{array}$ & $37 \%$ \\
\hline $\begin{array}{l}\text { Hydrogen } \\
\text { sulfide }\left(\mathrm{H}_{2} \mathrm{~S}\right)\end{array}$ & $0.20 \%$ & $\begin{array}{l}\text { Hydrogen } \\
\text { sulfide }\left(\mathrm{H}_{2} \mathrm{~S}\right)\end{array}$ & $0.20 \%$ \\
\hline
\end{tabular}

Table 3 Composition of biogas measured with Multitec model 540

According to Varnero and Arellano (1991), for the process to develop satisfactorily, the $\mathrm{pH}$ value in the digester not only determines the biogas production but also its composition ( $\mathrm{pH}$ should not fall below 6.0 or rise above 8.0). $\mathrm{A} \mathrm{pH}$ value below 6 indicates that the biogas generated is very poor in methane and therefore has lower energetic qualities. When the biogas has a methane content higher than $45 \%$, it is flammable (FAO, 2011). Table 1 shows $\mathrm{pH}$ conditions that allow methane generation, and Table 3 shows the composition of the biogas at day 30 of operation, showing $59.4 \% \mathrm{CH}_{4}$, which indicates flammability. The results of the physical-chemical parameters performed to the rumen content mixture of municipal slaughterhouse, are very close to the references of Falla, 1995 and Gonzalez, 2018.
The rumen content of the municipal slaughterhouse presented a $\mathrm{pH}$ of 7.11 close to neutrality, which is a determining factor in the methanogenic process. The calculated moisture percentage was $88.15 \%$, the percentage of solid matter (ST) was $11.85 \%$ and volatile solids (SV) were quantified at $87.2 \%$. The ratio of carbon and nitrogen content is $22 / 1$, which increases the production of bacteria to generate optimal conditions for biogas production.

\begin{tabular}{|c|c|c|c|}
\hline Parameter & $\begin{array}{c}\text { Rumen content } \\
\text { mix }\end{array}$ & \multicolumn{2}{|c|}{ Reference } \\
\hline $\mathrm{pH}$ & 7.11 & $\begin{array}{l}6.5- \\
7.5\end{array}$ & Falla, L. \\
\hline$\%$ Humidity & 88.15 & 85 & Falla, L. \\
\hline$\% \mathrm{ST}$ & 11.85 & 14.63 & $\begin{array}{l}\text { González, } \\
\text { R. }\end{array}$ \\
\hline$\%$ Ash & 12.8 & 27.06 & Falla, L. \\
\hline$\% \mathrm{SV}$ & 87.2 & 81.16 & $\begin{array}{l}\text { González, } \\
\text { R. }\end{array}$ \\
\hline \% Lipids & 4.54 & 9.60 & Falla, L. \\
\hline$\% \mathrm{C}$ & 22 & 20 & Falla, L. \\
\hline$\% \mathrm{~N}$ & 1 & 1 & Falla, L. \\
\hline $\mathrm{C} / \mathrm{N}$ & $22 / 1$ & $20 / 1$ & Falla, L. \\
\hline
\end{tabular}

Table 4 Physicochemical parameters of rumen content at the municipal slaughterhouse

Own Source

\section{Stage 4. Flame test}

A small burner was attached to the biogas outlet hose, testing its ignition. Figure 7 shows the intense blue coloration obtained from the flame on the 30th day of operation of the biodigester, which indicates that the biogas has a high calorific value, which will allow heating and flammability. If the gas burns with a bluish flame and good consistency, normal use of the biogas can be initiated (FAO, 2011).

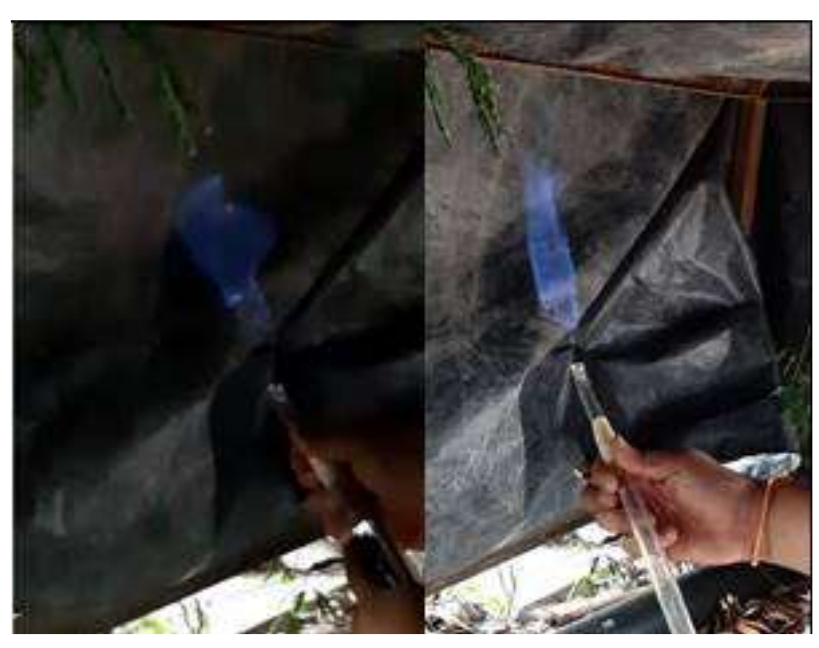

Figure 7 Flame test, intense blue coloration Own Source 


\section{Acknowledgements}

We would like to thank the Rastro Municipal de Ciudad Valles that collaborated with the contribution of the residues for this research, as well as the Chemistry Laboratory of the Instituto Tecnológico de Ciudad Valles, for the facilities provided for the physical-chemical analysis of the rumen content.

\section{Conclusions}

The floating bell biodigester prototype demonstrated that the organic waste (rumen content, blood, cattle excreta and viscera pieces) from the municipal slaughterhouse generates an important percentage of methane $\left(\mathrm{CH}_{4}\right)$ in the anaerobic digestion process, and can be captured in a reservoir to be used later in the water heating processes for carcass dressing and cleaning of the facilities. In addition, the characteristics of this biodigester system are adapted to the situation of lack of space in the municipal slaughterhouse.

The average daily biogas production of $0.180 \mathrm{~m}^{3}$ obtained in this prototype demonstrates that it is possible to obtain a higher percentage of biogas production with organic waste. Once these results are obtained, a feasibility study is expected to be carried out for a floating bell biodigester system according to the amount of organic waste generated monthly at the municipal slaughterhouse that considers the implementation costs of a project of this magnitude.

\section{References}

Dirección General de Inocuidad Agroalimentaria, Acuícola y Pesquera. 2020. Directorio de Establecimientos TIF. Recuperado el 09 de mayo del 2021 https://dj.senasica.gob.mx/SIAS/Statistics/Inoc uidad/EstabTIF

Dirección General de Inspección Fitozoosanitaria. 2020. Listado de Rastro y/o Centros de matanza en los que se realiza vigilancia o seguimiento operativo por parte de las entidades federativas. Año 2020. Recuperado el 09 de mayo del 2021 https://www.gob.mx/senasica/documentos/direc torio-de-padron-de-rastros
Falla, L. (1995). Desechos de matadero con alimento animal en Colombia. Frigorífico Guadalupe S. A. Santa fe de Bogotá Colombia.

García, J. y León E. (2015). Diseño y construcción de un biodigestor hindú Anaerobio en la finca Los Cuencanos de la Parroquia García Moreno. [Tesis de Licenciatura]. Escuela Superior Politécnica de Chimborazo, Ecuador. Repositorio Institucional DSpace ESPOCH http://dspace.espoch.edu.ec/handle/123456789/ 4863.

González, R. (2018). Estudio de Factibilidad para la Producción de Biogás a Partir de los Residuos Orgánicos del Rastro Municipal de Juigalpa, Nicaragua. (ONUDI)

Hernández, A. (2013). El potencial de los biodigestores como técnica sostenible para la producción de biogás en la Comunidad Indígena Nuevo San Juan Parangaricutiro, Michoacán. [Tesis de Licenciatura]. Universidad Autónoma del Estado de México Facultad de Planeación Urbana y Regional. Repositorio Institucional RI. http://hdl.handle.net/20.500.11799/58557.

Varnero, M.T. FAO (2011). Manual del Biogás. Santiago, Chile. ISBN 978-95-306892-0 .Proyecto FAO.

Varnero, M.T. y Arellano, J. 1990. Aprovechamiento racional de desechos orgánicos. Ministerio de Agricultura (FIA). Universidad de Chile. Facultad de Ciencias Agrarias y Forestales, Informe Técnico. Santiago, Chile, 98p.

Vidal, E.,Mojica, C.,Acosta, D.C., Reyes, A.(2021). Estudio de los residuos orgánicos de un rastro municipal, para su aprovechamiento en la generación de energía calorífica. Congreso Internacional de Investigación de Academia Journals Puebla 2021 Vol. 13, No. 7. 